\title{
Competitiveness of the national economy: current aspects of management
}

\author{
N. Kuprina' ${ }^{1}$, Kh. Baraniuk ${ }^{1}$, K. Vaskovska ${ }^{1}$ \\ ${ }^{1}$ Department of Accounting and Auditing, Odessa National Academy of Food Technologies, Odesa, Ukraine
}

\section{Article Info}

Received Dec 6, 2018

\section{Keyword:}

Competitiveness;

Methods of evaluation;

Subjects of the national economy;

The national economy.

\begin{abstract}
The study has allowed to systematize the classification of levels of competitiveness depending on the hierarchy of the object of study in the national economic system, as well as to highlight the level of the research of the object of competitiveness taking into account the functioning of the business entity, to identify the pattern between the competitiveness of the national economy of the country and its subjects - enterprises. The considered approach to the structuring of research activities of an enterprise as an economic object, allows you to select the internal and external competitiveness of the enterprise depending on the level of its assessment, which requires the formation of a system of indicators for its assessment. In the context of the study, another aspect of the analysis of the essence of competitiveness is the study of existing methods of its assessment at the enterprise, and as a result of suggestions for improvements, a methodical approach to the analysis of the competitiveness of an industrial enterprise, taking into account factors influencing the external environment in which it operates - CEF analysis allows you to conduct a comprehensive analysis of the competence and efficiency of the enterprise with the help of a system of performance indicators, to identify reserves and develop recommendations to ensure its competitiveness. Effective management of enterprise competitiveness is possible through the improvement of the structure of the organizational and economic system of managing it, described and improved by us.
\end{abstract}

\section{Corresponding Author:}

Baraniuk Khrystyna,

Department of Accounting and Auditing,

Odessa National Academy of Food Technologies,

Kanatna str., 112, Odesa, Ukraine.

Email: baranyuk.kristina@gmail.com

\section{Introduction}

The process of globalization and integration leads to rapid changes in the economic sphere of the country: trade liberalization, the country's open domestic market and increased competition on it, requires state synchronization of quality standards, restructuring of individual sectors of the economy and enterprises in order to strengthen their activities nationally and consolidate on the global markets. Globalization processes affecting the development of national economies currently require searching for methods to protect domestic producers, promoting the preservation of competitiveness and efficiency of enterprises, as well as introducing innovations in all areas of their activities, creating and promoting environmentally safe and high-quality products. In the conditions of changes on external and domestic markets, there is a need to adapt industrial enterprises to them, and a country that has well-functioning and competitive business entities that develop in an intensively changing external environment and shape their activities in accordance with their development strategies acquires proper competitiveness [1]. Therefore, the priority task facing the subjects of the national economy - enterprises of any industry in modern development conditions, is to ensure their competitiveness and effective management of it. This also applies to the most promising sector - small business, the 
development of which is one of the most important issues in improving the efficiency of enterprises [2]. Studies show that despite the fact that it is at large enterprises, that income is much higher than in small businesses, but it is small businesses that provide stable employment and a more even distribution of wealth among the population, so there is a smaller gap between the wages of managers and workers at small business enterprises, at the same time the range of such enterprises will be much larger. With a significant number of small businesses, the level of competition increases, the competitiveness of enterprises increases, therefore the price of products will decrease, the range will increase, and the quality will also increase. Moreover, in case of bankruptcy of such a business, there will not be such a tangible economic and social impact, for example, in the event of bankruptcy of a large conglomerate enterprise [2], [3]. Many scientists devote their publications to the research on issues of competition and competitiveness, as objects of study, the possibilities of ensuring the increase of competitiveness of enterprises and the national economy, including food industry enterprises and its management. Among them, the following economists have made a significant contribution to the study of competition and competitiveness, their various aspects: Yu. Afanasieva, A. Alokhin, L. Andrieieva, L. Antoniuk, H. Azoev, L. Balabanova, Dzh. Bauer, E. Brul, B. Burkynskyi, V. Burlakov, A. Butenko, A. Daian, R.A. Fatkhutdinov, I. Gerchikova, V. Haharinova, A. Hermanchuk, G. R. Hicks, O. Holubenkova, T. Hrynko, H. Ispirian, Yu. Ivanov, B. Karlof, T.B. Kharchenko, V. Koreniev, A. Kostin, F. Kotler, O. Kotlubai, E. Kovalenko, L. Kurbatska, A. Levytska, Dzh. Lodzh, V. Lysiuk, V. Malytska, H. Menken, E. Minko, A. Ollyve, M. Onopriienko, V. Osypov, L. Piddubna, M. Porter, M. Pustova, O. Rossykhyna, P. Saifulin, S.I . Savchuk, V. Shamrai, A. Sheremet, D.B. Stanko, L. Taison, T. Tkachenko, A. Tompson, R. Ursi, N. Verkhohliadova, V. Vlasova, E. Vyshnevetska, N. Zadorozhna, L. Zakrevska, R. Zhovnovach, Dzh. Ziusman, and others, but the issues of competition and competitiveness are relevant and currently valid [4], [5], [1]. In the works of V. Dubnytskyi, H. Kleiner, A. Kovalov, I. Larionov, V. Liashenko, K. Pavlov, E. Popov, A. Tatarkin O. Ynshakov, and others, the problems were considered of nano-, mini-, micro-, meso-, macro- and megaeconomics in order to clarify the subject, object and method of the analysis of economic systems and their elements. Competitiveness as an economic category explored at various levels of functioning of the subjects was considered by such Ukrainian scientists as Yu. Bielienkyi, B. Burkynskyi , B. Danylyshyn, B. Havrylyshyn, V. Heits, S. Khaminich, V. Korenevyi, I. Kriuchkova, B. Kvasniuk, V. Moroz, T. Reshetylova, R. Zhovnovach, and others, but in modern conditions this issue remains relevant, since the competitive struggle between economic actors occurs at all levels of the economic system [1]. Thus, the study of issues of competitiveness of the national economy at various levels of the study of its objects does not lose its relevance and currently requires a search for new approaches and aspects of its study.

\section{Materials and methods}

The relevance of the issues highlighted and the need for further research determined the choice of directions, goals and methods of this study. Thus, the purpose of the research in this article is: to substantiate the concept of competitiveness depending on the hierarchy of the objects of its research in the national economic system, as well as the types of competitiveness in terms of the level of its assessment; to improve the methodological approach to the analysis of the competitiveness of an industrial enterprise, taking into account the factors influencing the external environment in which it operates, to determine areas for further research. This study is conducted by the authors in accordance with the thematic plans of the research work of Odessa National Academy of Food Technologies, in accordance with the plans of state budgetary research "Development of food industry enterprises under the influence of globalization processes in the Ukrainian economy" (state registration number 0109U000770, 2009-2010), "Methodology for restructuring food industry enterprises in the context of the impact of globalization processes on the economy of Ukraine" (state registration number 0111U000323, 2011-2013), "Financial and economic safety of enterprises of the food industry of Ukraine: scientific and methodological problems of accounting, analysis and auditing", "Economic problems of accounting, analysis and auditing of economic activities at enterprises of the food industry" in order to increase the efficiency of functioning of enterprises of the food industry and their management. The theoretical and methodological basis of the research are domestic and foreign literary sources on this issue, information materials on Internet sites, as well as other official documents and materials. To solve the problems of the study the following methods were used: the method of structural and logical analysis in the formation of the structure and logic of the article; analytical-comparative analysis and classification method for the study of the essence of the concept of "competitiveness"; the grouping method and the abstract-logical method for classifying levels of competitiveness of the national economy and its research, grouping method 
for relative and absolute values for improving the method of analyzing the competitiveness of an industrial enterprise and forming a system of indicators for its implementation.

\section{Results and discussion}

As the analysis of publications has shown, the category of "competitiveness" in studies of both Ukrainian and foreign scientists is interpreted differently and is a broader concept that does not have a unified approach to the definition, both in essence and in types (Fig. 1) [6].

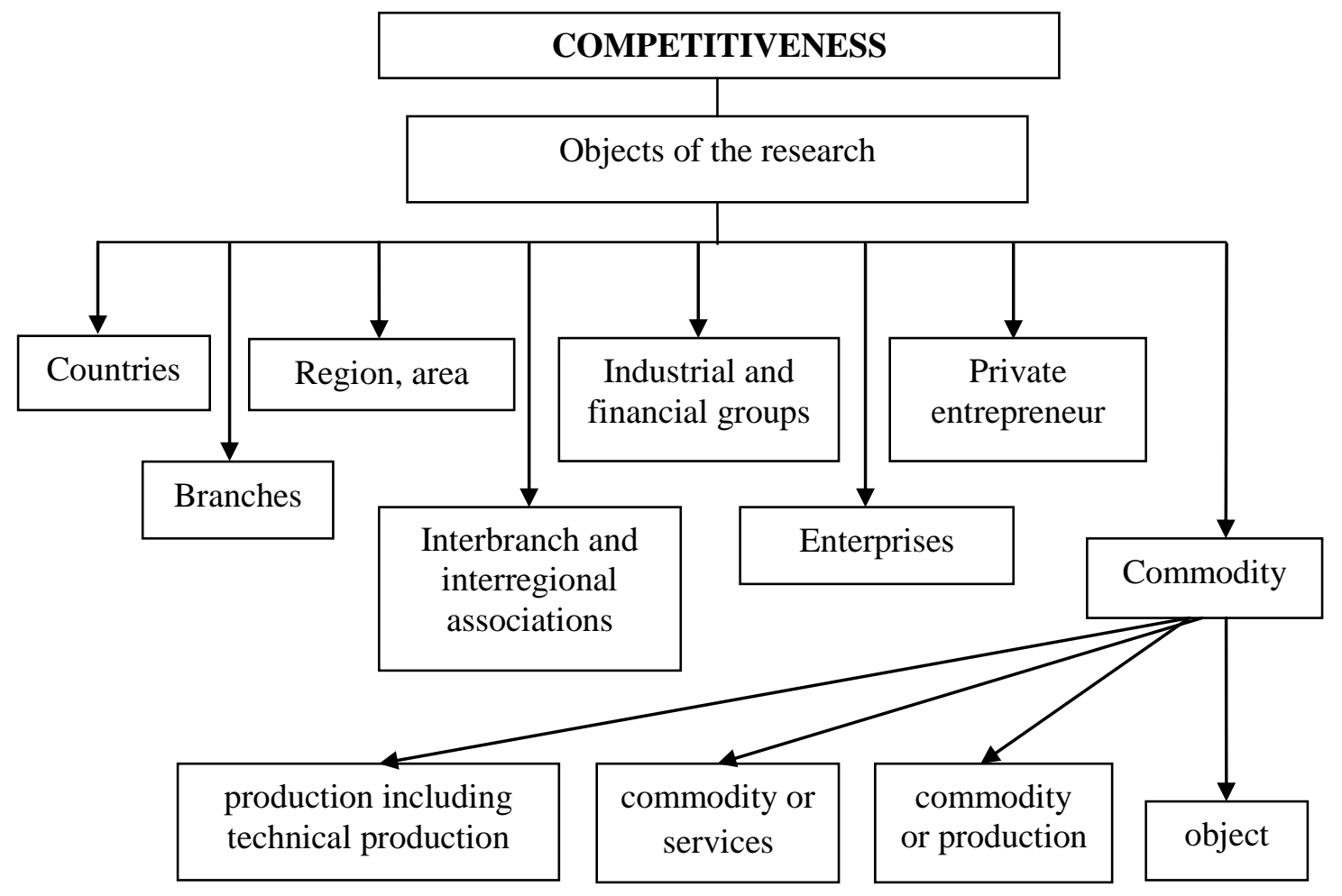

Figure 1: Types of the objects of competitiveness research [6]

As the analysis of the publications of the scientists showed [6], [5] :

1. The essence of the category "Competitiveness" was investigated by the authors: M. Porter, T. T. Hrynko, O. Cherneha, R. Fatkhutdinov, V. Vasilenko, V. Dikan, O. Bilorus, Yu. Matseiko and others. So, according to M. Porter, "competitiveness" is conditioned economic, social and political state of the country or individual producers in the domestic and foreign markets and property of goods, services, the subject of market relations to act on the market along with similar goods, services or competing subjects of market relations present on the market [7].

2. The country's international competitiveness has been studied by the scientists: L. Antoniuk, N. Hrazhevska, O. Shnypko and others, and represents "The country's ability to create such a national business environment on a free and fair market in which domestic producers can constantly develop their competitive advantages and hold and maintain stable positions in certain segments of the world market" [8].

3. The works of M. Porter, N. Kaliuzhnova and other scientists are devoted to the studies of the competitiveness of the region, the area and these studies were investigated at the World Economic Forum [9]. "The productivity of the use of regional resources, primarily labor and capital, compared with other regions, is characterized by the gross regional product per capita, as well as its dynamics", according to M. Porter, and is the competitiveness of the region that is being studied [7].

4. The competitiveness of the enterprise was investigated by such scientists as: B. Karlof, J.R. Hicks, V.Vlasova, G. Azoev, Y. Blank, D. Chervanev, L. Reikova, Z. Fatkhutdinov, L. Balabanova, K. Enok and others. J.R. Hicks' studies showed that the firm's competitiveness is a "comparative advantage in relation to other firms of this industry in the country and abroad" [10] and Y. Blank believes that this is "the system of evaluation characteristics of the economic activity of the enterprise, which affect the results of competition with other enterprises on the consumer market" [11]. 
5. Competitiveness of an enterprise, as a subject of the national economy, is not possible without the production of a competitive goods or product, the performance of work or the provision of services that are successful in the market and satisfy the specific needs of the consumer.

The studies have shown [1] that, competitiveness is a complex economic category, the definition of the essence of which is influenced by the totality of factors and levels of the economic system, such as the national economy:

- property of any economic subjects, which is caused by objective processes occurring in economic systems and manifests itself regardless of the desire of the object of economic activity [12];

- a multilateral and multi-level category, which is an integral characteristic of an economic entity relative to its compliance with objective (external relative to its) economic conditions in a market economy [13];

- a complex economic category, in which it is necessary to take into account the hierarchy of certain levels and factors of its formation and provision of the national economic system at all levels [14].

Quite a lot of attention is paid to the research on competitive objects at the micro-, meso- and macro- levels. Thus, according to V. Korinev and R. Zhovnovach [14], competitiveness covers: the macro-level (competitiveness of the country); meso-level (competitiveness of the region, competitiveness of the industry); micro-level (enterprise competitiveness, product competitiveness). In our opinion, object structuring should be based not only on the three-level differentiation of the economic system as a set of elements, but also on distinguishing the levels of accommodation of the object of study in this system and the level of the object of study of its competitiveness. If we take into account the traditional way of structuring the economic system, then the international economy considers the division of such a system into countries, their functioning and interaction; mesoeconomics deals with regions, industries and complexes, minieconomics deals with enterprise divisions, nanoeconomics deals with individuals and their groups (collectives of enterprise subdivisions) [15]. Such object structuring of the economy, in the opinion of A. Tatarkin and E. Popov, should also be supplemented by megaeconomics or the global economy, which reflects the mega-level of studying objects [15].The study of the market transformation process of the economic complex of the region by V.I. Dubnitsky, confirms the concept of five levels of economic science and division of the economy, and taking into account the combination of all intermediate formations within one medium level and separating the enterprise as an independent one, the sequence is distinguished - megaeconomics $\rightarrow$ macroeconomics $\rightarrow$ mesoeconomics $\rightarrow$ microeconomics $\rightarrow$ nanoeconomics [16].

The works of many scientists, such as V.I. Dubnytskyi, O.V. Inshakov, G.B. Kleiner, K.V. Pavlov, I. K Larionov, V.I. Lyashenko are devoted to: the research on the problems of structuring the economy and analyzing various objects of economic systems at nano-, micro-, meso-, macro, and mega-levels, as the studies have shown [1]. However, modern studies of the activities of enterprises and their competitiveness at various levels of the economic system, the formation of various associations of enterprises, sectoral and inter-sectoral complexes, the emergence of regional and interregional associations require further theoretical substantiation and search for practical solutions. As the studies have shown, according to V.I. Lyashenko and K.V. Pavlov, the necessary conditions for the economy of Ukraine, have matured as well as the resources, goals, interests of functioning and development, general by content and forms of the results of the activities of associated economic agents at each meso-level to form them in various complexes. In addition, the meso levels, as noted by V.I. Lyashenko, unlike the main ones, are subject to adaptation transformation, strategic changes and can be completely absent under certain circumstances in real economic systems (absence of an enterprise, TC, integration alliances or their size) [17]. So, O. I. Inshakov proposes to call four intermediate levels between two neighboring five major levels (mega-, macro-, micro-, mini-, nano-levels) each mesoeconomic, each of which consists of groups of integrated subjects of the previous level [18]. The author of this article agrees with the opinion of G. B. Kleiner, that "economic relations do not extend to all such groups (for example, the relationship between professional groups of workers, which, according to O. Inshakov, is intermediate between the nano- and mini-, meso-level, is not usually of an economic nature" [19], in addition, the integration covers the subjects not only of the previous level, but may also spread to other levels. Therefore, as a rule, one meso-level is distinguished (between micro- and macro- levels).

Thus, the study allowed to systematize the classification of levels of competitiveness depending on the hierarchy of the object of study in the national economic system, as well as to identify the level of research of the object of competitiveness (Table 1) taking into account the functioning of the business entity and the level of research of its activity for more systematic analysis of competitiveness of the subject of national economy and managing its competitiveness [1]. 
Table 1: Level of competitiveness depending on the hierarchy of the object of the study

\begin{tabular}{|c|c|c|c|c|}
\hline $\begin{array}{l}\text { Levels of } \\
\text { national } \\
\text { economic } \\
\text { system }\end{array}$ & $\begin{array}{l}\text { Levels of } \\
\text { placement of the } \\
\text { object of study } \\
\text { in the national } \\
\text { economic } \\
\text { system }\end{array}$ & Levels of competitiveness & $\begin{array}{l}\text { The level of } \\
\text { research of } \\
\text { competitiven } \\
\text { ess object }\end{array}$ & $\begin{array}{l}\text { Levels of business } \\
\text { activity research } \\
\text { of the entity }\end{array}$ \\
\hline Macro-level & Macro-level & Country competitiveness & Macro-level & macroeconomic \\
\hline \multirow[t]{4}{*}{ Meso-level } & Meso-level IV & $\begin{array}{l}\text { Competitiveness of interregional } \\
\text { and interbranch associations, } \\
\text { industrial groups, industrial and } \\
\text { financial groups, etc. }\end{array}$ & \multirow[t]{3}{*}{ Meso-level } & \multirow{5}{*}{ mesoeconomic } \\
\hline & Meso-level III & Competitiveness of the region & & \\
\hline & Meso-level II & Competitiveness of industries & & \\
\hline & Meso-level I & \multirow{2}{*}{$\begin{array}{c}\text { Competitiveness of diversified } \\
\text { network structures as voluntary } \\
\text { associations (clusters, technology } \\
\text { parks) }\end{array}$} & \multirow[b]{2}{*}{ Micro-level } & \\
\hline \multirow{3}{*}{ Micro-level } & Micro-level II & & & \\
\hline & \multirow{2}{*}{ Micro-level I } & Competitiveness of enterprises & \multirow{2}{*}{ Mini-level } & \multirow{2}{*}{$\begin{array}{l}\text { - microeconomic } \\
\text { - minieconomic } \\
\text { - nanoeconomic }\end{array}$} \\
\hline & & Competitiveness of products & & \\
\hline Nano-level & Nano-level & $\begin{array}{l}\text { Competitiveness of products of a } \\
\text { private entrepreneur - physical } \\
\text { person }\end{array}$ & Nano-level & nanoeconomic \\
\hline
\end{tabular}

The national economic system refers to the economy of a country in which four levels are distinguished: macro, meso, micro, and nano levels. So, from tab. 1 we can see that the selection of certain elements (object structuring) to study competitiveness allowed us to identify [1]:

- nano-level - the competitiveness of products of a private entrepreneur (individual), representing the nanolevel (first level, minimum level of its research) as both the placement of the object of research in the economic system, and the level of research of the object of competitiveness;

- two micro levels - product competitiveness and enterprise competitiveness (micro level I), representing the mini-level (the second level of competitiveness research), as well as competitiveness of diversified network structures as voluntary associations (clusters, technology parks), (micro-level II), reflecting the micro level (the third level of competitiveness research);

- competitiveness of cluster structures as a tool to protect domestic producers and preserve its efficiency and competitiveness, it has been proposed to allocate a separate basic element in this structuring, contributing to further diversification and the basis for the formation of industry, intersectoral, regional and interregional associations and national transnational structures, which requires separate (the third) level of competitiveness research, representing both the micro level II and the meso level I of the location of the object of study in the national economic system, as well as the study of such structural associations as a single system and the separate functioning of each of its elements;

- four mesolevels, reflecting the meso-level of the research of the object of competitiveness, highlighting the competitiveness of the industry, competitiveness of the region, as well as the competitiveness of interregional and intersectoral associations, industrial groups, IFG, etc.;

- macro-level - the competitiveness of the country, reflecting the macro-level (the fifth level) of the research object competitiveness.

Another aspect of this structuring is the study of a business entity (in the context of this study - an enterprise or a private entrepreneur - an individual) as an economic object, according to which: megaeconomic, internationaleconomic, macroeconomic, meso, micro-, mini-, nanoeconomic visions have been distinguished [19]. The conditions for the preservation of the economic sustainability of the national economy in modern conditions are not only solving short-term tasks, but also long-term foundations of competitiveness, which will contribute to the effective functioning of the economy in the future. Competitive economies, according to 
Xavier Sala-I-Martin, a professor of economics at Columbia University, "are those economies that have factors that increase their productivity, on which their present and future prosperity is built" [20]. The concept of "competition", as the study showed, according to A. Porter, is significantly influenced by the globalization process, which highlights the concept of "competitive advantage" instead of comparative, which allows a company not only to work productively, but to constantly improve the ways of competition and increase productivity through the use of innovations not only in production, but also in marketing activities and in the provision of services. A. Porter notes that countries or regions create an environment that promotes or does not contribute to the competitiveness of firms, therefore firms are competing, not countries or regions [21].

Taking into account the feature of the "Neisbitt paradox", there is also an inverse relationship: the stronger the individual participants of the globalized market who have high competitiveness (among such participants are the enterprises producing goods and services), the higher the level of wealth and strength of the internal relations of the society of a particular state and, globalization of the national economy of the country and its global competitiveness [22] (Fig. 2). Thus, the competitiveness of the subjects of the national economy and the efficiency of their functioning - enterprises and their associations, among other things, is important for the competitiveness of the national economy. It is well known that the activity of any enterprise is getting a profit and is aimed specifically at the process of selling its own products or goods purchased for implementation. Consequently, the implementation of an industrial enterprise object is the main task and the ultimate goal of its activities, and also serves as the last stage of the industrial enterprise assets cycle, the completion of which determines the financial result of its activities, production efficiency and competitiveness of these objects. The study made it possible to improve the definition of the essence of the category "competitiveness", which was cited by I. Gerchikova and characterize it from the point of view of an industrial enterprise as a set of quality and cost characteristics of an industrial enterprise selling object that satisfies a specific consumer need; the complex of consumer and cost characteristics of which determines its success on the market, i.e. the ability of the object to be exchanged for money in the conditions of a broad supply [5].

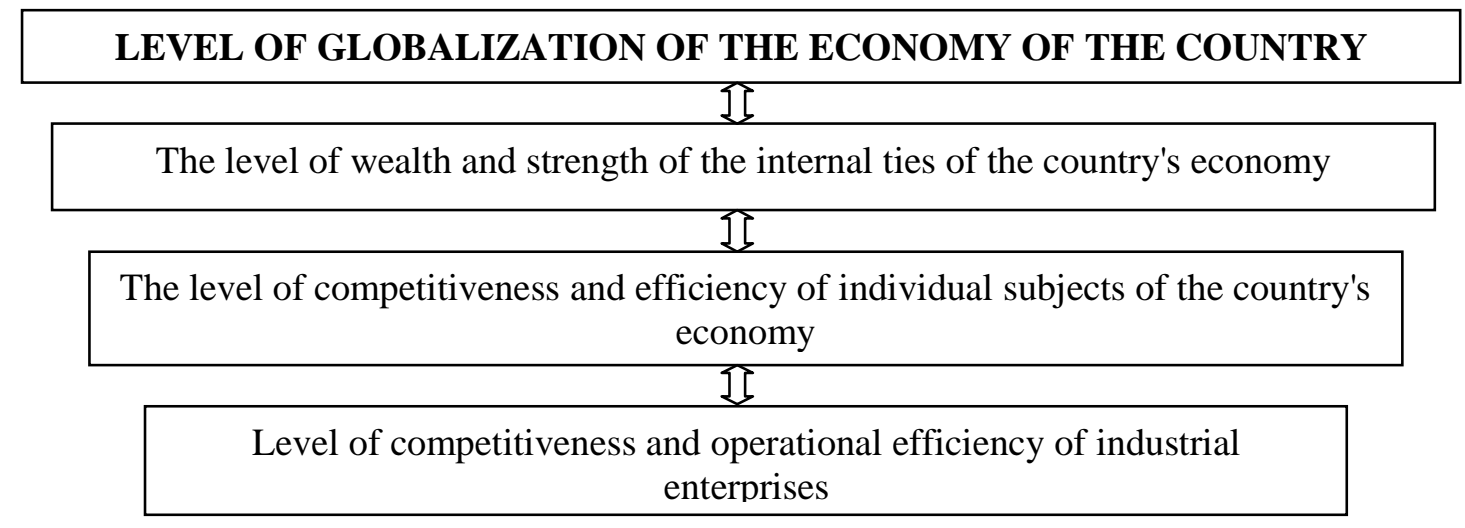

Figure 2: Dependence of the level of globalization of the country and the competitiveness of industrial enterprises [23]

In previous studies [24], we have identified the main methods for assessing the competitiveness of an industrial enterprise, including small businesses (Table 2) and highlighted groups of indicators needed to calculate the level of competitiveness, which were based on the method built on the theory of the effective competition. Quantitative methods for assessing competitiveness help evaluate the ability of an enterprise to make effective management decisions and assess the ability of an enterprise to capture strategic economic zones in a competitive struggle in the external environment and are based on the calculation of certain indicators using relative values that are combined into group and integral indicators. However, in our opinion, to assess the competitiveness of such a subject of the national economy as an enterprise, it is necessary to choose precisely combined methods that are systemic in nature but are not cumbersome and difficult to calculate and conduct such analysis. Therefore, the synthesis of the theoretical aspects of assessing the competitiveness of the enterprise and the practical aspects of the operation of the enterprise itself has allowed to improve the methodological approach to the analysis of the competitiveness of an industrial enterprise, 
Table 2: Basic methods for assessing the level of competitiveness of enterprises (fragment)*

\begin{tabular}{c|l}
\hline Methods & \multicolumn{1}{c}{ Characteristic methods } \\
\hline $\begin{array}{c}\text { Methods of evaluation } \\
\text { market share } \\
\text { competitiveness }\end{array}$ & $\begin{array}{l}\text { Distributes subjects of market activity to: outsiders, subjects with low, medium } \\
\text { and strong competitive position and leaders of market activity. The magnitude } \\
\text { of changes in market share allows you to determine certain groups of business } \\
\text { units, the size and dynamics of market shares gives you the opportunity to build } \\
\text { a competitive market map, which determines the degree of market dominance, } \\
\text { features of the development of a competitive situation. }\end{array}$ \\
\hline $\begin{array}{c}\text { Methods based on the } \\
\text { theory of effective } \\
\text { competition }\end{array}$ & $\begin{array}{l}\text { Comparison of the position of industry enterprises with competing enterprises } \\
\text { and industry average indicators by groups of indicators (efficiency of production } \\
\text { and marketing activities of an enterprise, financial stability, quality of an } \\
\text { enterprise's products). The advantages of this method are those with the help of } \\
\text { which it it becomes possible to identify the weaknesses and strengths of the } \\
\text { enterprise in relation to another, assess the lag gap, develop management actions } \\
\text { to strengthen the weaknesses. }\end{array}$ \\
\hline
\end{tabular}

Matrix and graphical methods for assessing competitiveness

Portfolio Analysis Method

SWOT- Analysis

Index method or method based on the assessment of product competitiveness

Methods based on comparative advantages analysis

Benchmarking method * Compiled on the basis of the sources: [4], [24], [5], [25], [26], [27], [28], [29], [30], [31], [32], [33].

Study of the development of competitiveness in dynamics. The advantages of these methods are ease of understanding and clarity. Among the drawbacks of the matrix and graphical methods, it should be noted that they do not provide the necessary systemic view on competitiveness, do not take into account the different significance of factors of competitiveness.

A tool by which the enterprise determines its economic condition and the feasibility of investments in various areas of the enterprise's activities. The result of the analysis is a reduction or cessation of investments in the region, which do not bring profits to the company or, on the contrary, an increase of investments in attractive and promising projects or departments. The purpose of the analysis is to find and agree on the best strategies for the enterprise and expedient allocation of the company's financial resources. It is carried out thanks to matrix methods, of which the first and the most famous is the model of the Boston consulting group (BCG). The second matrix method is the matrix, which was represented by consulting firm McKinsey and General Electric (GE).

It consists in the collection of complete information about the internal situation at the enterprise, studying the characteristics of which the company has influence: the strengths of the enterprise, providing significant advantages among competitors, as well as the weaknesses of the enterprise in relation to competitors. At the same time, on the other hand, the external environment (market) is studied, which the company has no influence on: the opportunities that the market provides to the enterprise for expanding its own activities and the threats that reduce the attractiveness of the market for the enterprise.

The calculation takes into account such an important criterion as the competitiveness of the goods. According to this method, the competitiveness of the manufacturer depends on the competitiveness of its products. The ratio of two characteristics is used: quality and price, and thus, the most competitive is the product that has the optimum ratio of these characteristics.

The fact that an industrial enterprise has such advantages that enable it to ensure relatively low production costs (product quality and sales, production costs, value and profit rate of an enterprise, an enterprise segment on the industry market, etc.) compared to competitors.

The approach, the essence of which is the identification of enterprises, leading analysis of their strategies, the things they do better, and the study, improvement and application of the working methods of such enterprises in themselves. It is carried out within the framework of competitive analysis, but it is more detailed 
taking into account the influence factors of the external environment in which it operates - CEF-analysis (Fig. 3 ), which allows to conduct a comprehensive analysis of competence and efficiency of the operation of the enterprise through a system of performance indicators, identify reserves and develop recommendations to ensure its competitiveness.

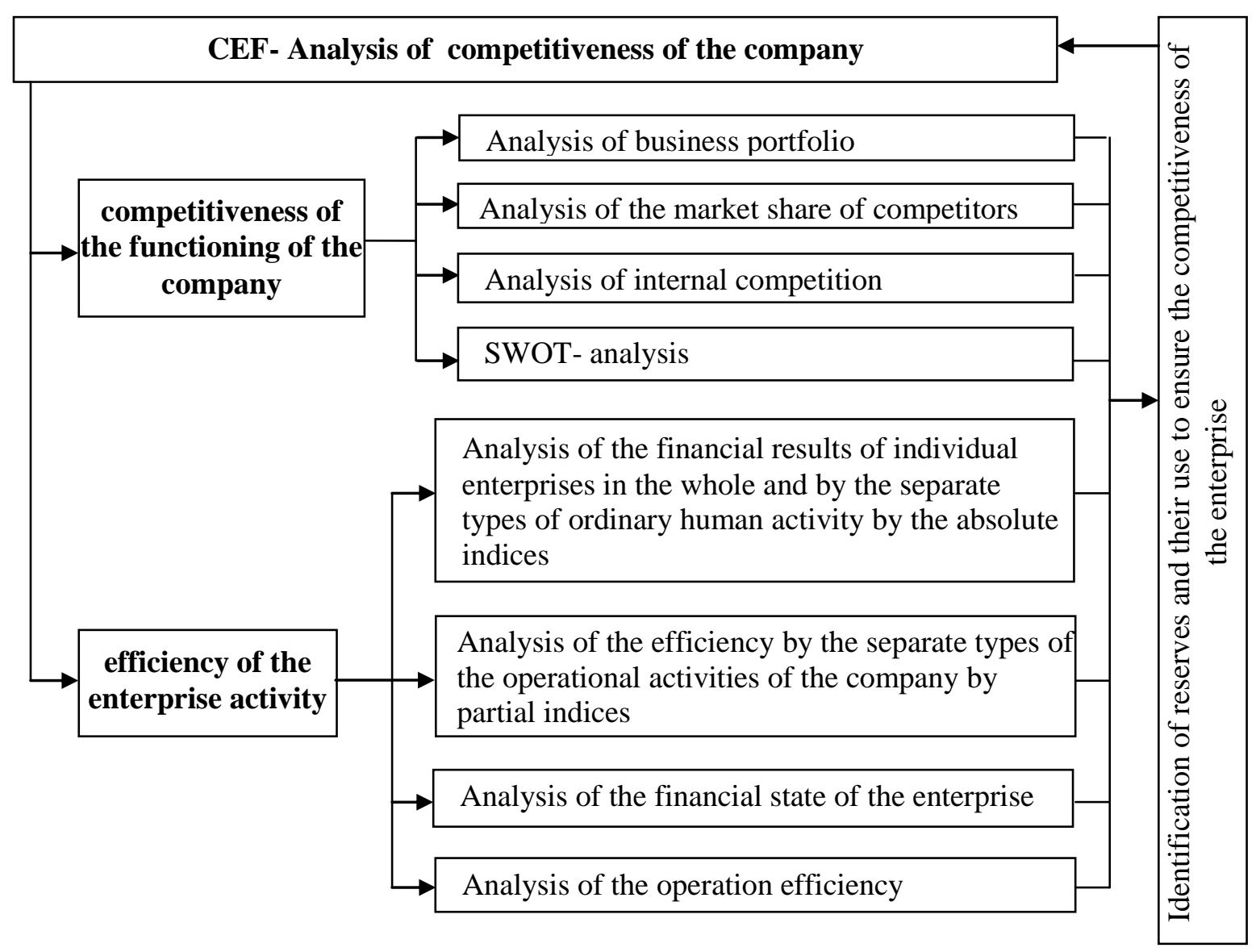

Fig. 3: The method of conducting CEF analysis of the competitiveness of the enterprise [5]

In our opinion, in order to carry out a complex analysis of the competitiveness of the enterprise, it is optimal to distinguish the concept of "the competence of the operation of an enterprise" in order to assess the factors of the influence of the external and internal environment of the enterprise's operation. Competency (from English Competent is the Ability [34] of functioning of an enterprise - the ability to form more favorable conditions for functioning on the consumer market in comparison with competitors through the creation and development of competitive advantages that have a consumer value [35], [5]. Through the analysis of the business portfolio (identification of potential development paths through the allocation of strategic zones of management by certain features: "average attractive" zone, "The most attractive" zone, the "moderately attractive" zone, the "least attractive" zone), the analysis of the market share of competitors (the level of enterprise dominance on the market and the possibility of its influence on the structure of demand, supply and sales volumes on the market), analysis of intra-industry competition (the structure of the area of operation of an enterprise: the intensity of competition, the competitive positions, the identification and study of the closest competitors) and factor-based SWOT-analysis (determining the most important factors of the internal characteristics of the enterprise and the external environment (market), the formation of interconnections of the strengths and weaknesses with opportunities and threats: competitive assets - the strategy of "huge opportunities", competitive liabilities - the strategy of "weakness - threat", market assets - the strategy of "weakness-opportunities", market liabilities - the strategy of "huge threat"), in our opinion, may well characterize the competitive functioning of the enterprise. The overall indicator of competency ( $\mathrm{I}_{\mathrm{kom}}$, expressed in points) gives an assessment of the competitiveness of the enterprise from the point of view of the competency of its functioning (formula 1): 


$$
\mathrm{I}_{\mathrm{kom}}=\mathrm{k}_{1} \cdot \mathrm{Str}+\mathrm{k}_{2} \cdot \mathrm{Sh}+\mathrm{k}_{3} \cdot \mathrm{IiC}+\mathrm{k}_{4} \cdot \mathrm{Env},
$$

where Str is an effective index of a business portfolio; Sh - the effective indicator of the market share of the enterprise in the total volume of sales on the market; IiC - an effective indicator of intra-industry competition; Env - factor assessments of environmental opportunities and threats; $\mathrm{k}_{1}, \mathrm{k}_{2}, \mathrm{k}_{3}, \mathrm{k}_{4}$ - coefficients of weightiness of the indicators (determined in an expert way) [35], [5]. In its turn, the assortment characteristic of the company's performance ( $\mathrm{I}_{\mathrm{komv}}$, expressed in points) is calculated for a more detailed analysis of the company's performance, taking into account the influence of the breadth of the range of products (formula 2):

$$
\mathrm{I}_{\mathrm{komV}}=\frac{\sum \mathrm{k}_{1} \cdot \sum \mathrm{tr}_{\mathrm{i}}}{\mathrm{n}}+\frac{\sum \mathrm{k}_{2} \cdot \sum \mathrm{h}_{\mathrm{i}}}{\mathrm{n}}+\frac{\sum \mathrm{k}_{3} \cdot \mathrm{IiC}_{\mathrm{i}}}{\mathrm{n}}+\mathrm{k}_{4} \cdot \mathrm{Env},
$$

where $\mathrm{Str}_{\mathrm{i}}$ is an effective index of the business portfolio of the $\mathrm{i}$-th assortment; $\mathrm{Sh}_{\mathrm{i}}$ - the effective indicator of the market share of the enterprise of the $\mathrm{i}$-th assortment; $\mathrm{IiC}_{\mathrm{i}}$ is an effective indicator of intra-industry competition and the range of products; Env - factor assessments of environmental opportunities and threats; $n$ - the breadth of the assortment (quantity of products sold by the enterprise), $\mathrm{k}_{1}, \mathrm{k}_{2}, \mathrm{k}_{3}, \mathrm{k}_{4}$ - coefficients of weightiness of the indicators (determined expertly) [35], [5]. The value of the general and assortimental indicator of competence should tend to grow. When comparing the indicators, its greater significance in relation to competitive enterprises indicates a more stable and strong position of the investigated enterprise in the market, a higher level of its competitiveness, and has a positive impact on the efficiency of its activities. The head of the company independently establishes the low limit of the indicators of competitiveness, taking into account the average value of these indicators of the nearest competitors in the industry. The analysis of the competitiveness of enterprises in terms of efficiency of its operation should be carried out with the help of a group of evaluation indicators: the analysis of the financial performance of the enterprise as a whole and by certain types of ordinary activities (absolute indicators of the formation of financial results characterize the financial results from the usual activity of the enterprise with an in-depth analysis of financial results from all types of activities, the analysis of costs per $1 \mathrm{UAH}$ of income), the analysis of the efficiency of certain types of operating and enterprise activities by private indicators (analysis of resource utilization efficiency, analysis of safety performance of the main operating activity, analysis of financial results of the enterprise activity as a whole and by certain types of usual activity by the relative indicators), analysis of the financial condition of the enterprise (analysis of liquidity and financial stability of an enterprise), analysis of the effectiveness of marketing service of enterprise activities (analysis of the sales effectiveness; analysis of indicators of production promotion).

Thus, the proposed CEF-analysis allows us to carry out a comprehensive analysis of the competitiveness of the industrial enterprise on all the important issues and to determine the influence of a number of factors and aspects of the activity of the enterprise itself under conditions of significant changes in the environment. The effective analysis of the competitiveness of an industrial enterprise occupies a significant place in the control system of its competitiveness. In our opinion, effective management of the competitiveness of the enterprise is possible by improving the structure of its organizational and economic management system, which includes: separate management functions important for such analysis: motivation (stimulation of the employees of the enterprise to purposefully and efficiently fulfill their functional duties), analysis (factor assessment, which affect the level of competitiveness of the enterprise, search and mobilization of the hidden internal reserves of the enterprise) and control (verification of conformity of functioning of the enterprise with the previous management decisions and directions of the strategy of its development and directions of effective activity); effective interaction of the departments of the enterprise, whose activities affect the competitiveness of the enterprise: the logistics department (directly implements effective budget control of stocks), the department of marketing and innovation (implements effective budget control of the process of implementation of finished products), the department of production and quality (engaged in organizing the production process and constant controlling of its quality in accordance with existing standards, is looking for ways to reduce the cost of production and improvement of its quality, compliance with the regulations and technological conditions of production and packaging of products), the financial department (engaged in planning, financing and accounting of production and sales processes, implements budget control of cash) and the internal control department (evaluation of the competence and efficiency of the operation of the 
enterprise, assessment of the effectiveness of the logistics department, the determination of the reserves for ensuring the competitiveness of the enterprise).

\section{Conclusion}

The study has allowed to systematize the classification of levels of competitiveness depending on the hierarchy of the research object in the national economic system, as well as to identify the level of the research of the object of competitiveness, taking into account the functioning of the subject of entrepreneurial activity and the level of study of its activities, to identify the regularity between the competitiveness of the national economy - the country and the competitiveness of its subjects - enterprises. The considered approach to structuring of the research of the company's activity as an economic object allows us to distinguish internal and external competitiveness of the enterprise depending on the level of its evaluation, which requires the formation of a system of indicators for its evaluation. In the context of the study, another aspect of the analysis of the essence of competitiveness is the study of existing methods for its evaluation at the enterprise, and as a result, suggestions for improvements, a methodological approach to the analysis of the competitiveness of an industrial enterprise, taking into account the factors of the influence of the external environment in which it operates, the CEF-analysis, which allows us to carry out a comprehensive analysis of the competitiveness and efficiency of the enterprise through the system of evaluation indicators, to identify the reserves and develop recommendations to ensure its competitiveness. In our opinion, effective management of the competitiveness of the enterprise is possible by means of improving the structure of its organizational and economic management system described and improved by us.

\section{Abbreviations}

$\begin{array}{ll}\text { CEF-analysis } & \text { A comprehensive methodological approach to the analysis of the } \\ & \text { competitiveness of the enterprise } \\ \text { Fig } & \text { Figure } \\ \text { GE company } & \text { General Electric company } \\ \text { IFG } & \text { Industrial and financial groups } \\ \text { model BCG } & \text { Model of the Boston Consulting Group } \\ \text { SWOT-analysis } & \text { Strengths, weaknesses, opportunities, threats-analysis } \\ \text { Tab } & \text { Table } \\ \text { TC } & \text { Transnational corporations }\end{array}$

\section{References}

[1] N.M. Kuprina, Konkurentosposobnost' deâtel'nosti predpriâtiâ: vidy i uroven' [The competitiveness of the enterprise: types and level]. Sci. collected works: Formuvannâ rinkovoï ekonomìki. Specìal'nij Vipusk "Regìonal'nij rozvitok Ukraïni: problemi ta perspektivi", part 1, Kyiv, 2011, pp. 564-571.

[2] N.M. Kuprina and Kh. O. Baraniuk, Pìdhodi do ocìnki konkurentospromožnostì pìdpriêmstv harčovoï promislovostì malogo bìznesu [Approaches to the assessment of the competitiveness of small businesses in the food industry] in Nemchenko V. (ed.), Naukovo-metodični problemi ocinočnoï diâl'nostì v Ukraïni [Scientific and methodological problems of valuation activity in Ukraine], Karavela, Kyiv, Ukraine, pp. 127-136, 2018.

[3] D. Pletnev, E. Nikolaeva and A. Campa, "Comparative analysis of criteria for classifying enterprises to small and medium business in different countries", Strategii biznesa, no. 9(17), pp. 30-36, 2015.

[4] Kh.O. Baraniuk, "Analysis and structuring of external and internal factors of influence on competitiveness of enterprise", Food industry economics, Vol. 9, issue 1, pp. 30 - 37, 2017.

[5] K.O. Vaskovska, "Development of the management of the competitiveness of food industry enterprises", Ph.D. Thesis, specialty 08.00.04 - Economics and management (by economic activity), The Institute of Market Problems and Economic and Ecological Researches of the National Academy of Sciences of Ukraine, Odessa, Ukraine, 2014. 
[6] Kh.O. Baraniuk "Competitiveness: essence and objects of the research", Food industry economics, Vol. 8, issue 4, pp. 33 - 39, 2016.

[7] M. Porter, On Competition, Vil'âms, Moscow, Russia, 2005.

[8] L. Antoniuk, Mižnarodna konkurentospromožnist' kraïn: Teoriâ ta mehanizm realizacï̈ [International Competitiveness of Countries: Theory and Mechanism of Implementation], KNEU, Kyiv, Ukraine, 2004.

[9] K. Schwab (Ed.). (2009). The Global Competitiveness Report 2009-2010 (pp. 1-495, Rep.). The World Economic Forum. Geneva. Retrieved December 19, 2018, from http://www3.weforum.org/docs/WEF_GlobalCompetitivenessReport_2009-10.pdf

[10] J.R. Hicks, Stoimost' i kapital [Value and Capital], Progress, Moscow, Russia, 1993.

[11] I. Blank, Torgovyj menedžment [Trade management], Ukrainsko-finskij institut menedžmenta i biznesa, Kyiv, Ukraine, 1997.

[12] T. Reshetilova and S. Dovhan, Marketingovì doslidžennâ [Marketing researches], Dnipropetrovsk, Ukraine, 2007.

[13] S. Khaminich, "The method of integrated assessment of the level of competitiveness of an industrial enterprise", Ekonomist, no.10, pp.59-61, 2006.

[14] V. Koriniev and R. Zhovnovach, "Assessing the competitiveness of the objects and subjects of management", Visnyk of Zaporizhzhya National University, no. 2(10), pp. 45-52, 2011.

[15] G.B. Kleiner (ed.), The mesoeconomy of the transition period: markets, industries, enterprises, Nauka, Moscow, Russia, 2001.

[16] V.I. Dubnitskii, Transformaciâ promyšlennogo kompleksa regiona v kontekste marketingovoj koncepcii [The transformation of the region's industrial complex in the context of the marketing concept], Vìsnik AEN Ukraïni, no. 1(5), pp. 101-110, 2004.

[17] V.I. Liashenko, Nanoeconomics, nanoindustry, nanotechnology: problems and prospects of development and management in the Slavic countries of the CIS, izd-vo Kol'skogo NC RAN, Murmansk - Donetsk, Russia, 2007.

[18] O.V. Inshakov, Urovnevyj analiz ob`ekta, predmeta i metoda èkonomičeskoj teorii [Level analysis of the object, subject and method of economic theory], Izv. SPbUÈF, no. 4, pp. 5-18, 2004.

[19] G.B. Kleiner, Nanoèkonomika i teoriâ firmy [Nanoeconomics and Theory of the Firm], Vesnik VGU, Seriâ Èkonomika i upravlenie, no. 2, pp. 99-123, 2004.

[20] World Economic Forum: Global Competitiveness Rating 2009-2010, Humanitarian technology news (2010). Humanitarian development of Russia and abroad: expert-analytical portal, available at: http://gtmarket.ru/news/state/2009/09/08/2166 (Accessed 20 December 2018).

[21] M. Porter, On Competition, Vil'âms, Moscow, Russia, 2001.

[22] N.M. Kuprina, Strategičnì naprâmki rozvitku pìdpriêmstv harčovoï promislovostì Ukraïni [Strategic directions of development of enterprises of the food industry of Ukraine] in Butenko A.I. (ed.), Strategičnì naprâmki rozvitku pidpriêmnic'kogo sektora Ukraïni [Strategic directions of development of the Ukrainian business sector], İnterprint, Odesa, Ukraine, pp. 282-301, 2011.

[23] N.M. Kuprina, Transformaciâ deâtel'nosti predpriâtij piŝevoj promyšlennosti Ukrainy v kontekste obespečeniâ ih èkonomičeskoj bezopasnosti [Transformation of the activities of the food industry of Ukraine in the context of ensuring their economic security] in Pavlov O.I. (ed.), Stalij rozvitok ta bezpeka agroprodovol'čoï sferi Ukrä̈ni v umovah globalizacijnih viklikiv [Sustainable development and safety of the agri-food sector of Ukraine in the context of globalization challenges], ONAHT, Odesa, Ukraine, pp. 256-272, 2012.

[24] Kh.O. Baraniuk, Pìdpriêmstva malogo bìznesu: doslìdžennâ metodìv analìzu konkurentospromožnostì [Small Business Enterprises: Researching of Competitive Analysis Methods] in Nemchenko V. (ed.), Rozvitok fìnansovoï sistemi sučasnogo pìdpriêmstva: oblikkovo-analìtičnij aspekt [Development of the financial system of a modern enterprise: accounting and analytical aspect], Fenìks, Odesa, Ukraine, pp. 217-230, 2017.

[25] M.M. Sharkadi, "Methodological bases of estimation of competitiveness of the enterprises", Naukovyi visnyk Uzhhorodskoho universytetu. Ekonomika, issue 29, part 2: Udoskonalennia obliku, analizu, audytu i zvitnosti v suchasnykh umovakh hlobalizatsiinykh protsesiv u svitovii ekonomitsi, pp. 217220, 2010. 
[26] V.V. Yatsura and M.V. Zamroz, "Analysis of methods for assessing the competitiveness of the enterprises", Visnyk Volynskoho instytutu ekonomiky ta menedzhmentu. Zbirnyk naukovykh prats, no. 2., pp. 84-89, 2011.

[27] L.M. Zakrevska, "Assessment and increasing the competitiveness of enterprises confectionery in Ukraine", Thesis abstract of Cand. Sc. (Econ.), 08.06.01, National University of Food Technology, Kyiv, Ukraine, 2006.

[28] B.V. Burkinskiy, E.V. Lazareva and I.N. Ageeva, Konkurentosposobnost produktsii i predpriyatiya [Competitiveness of products and enterprises], Odessa, Ukraine, 2002.

[29] A.P. Latkyn, Konkurentosposobnost rehyonalnoho proyzvodstva. Teoryia y praktyka. [Competitiveness of regional production. Theory and practice.], Vladivostok, Russia, 2000.

[30] L.V. Pashchenko and A.M. Fylynkov, "About systematization and disadvantages of methods for estimation the competitiveness of enterprises", Aktualnyie problemyi konkurentosposobnosti predpriyatiy [Actual problems of competitiveness of the enterprises], Materialyi Vseukrainskoy nauchno-prakticheskoy konferentsii studentov, aspirantov, molodyih uchYonyih [Proceedings of the All-Ukrainian scientific-practical conference of students, graduate students, young scientists], (Sevastopol, 22-23 April 2010), pp. 158-159, 2010.

[31] N.O. Pustova, "Organizationally economic mechanism of providing the competitiveness of enterprises (by materials of food enterprises of the Kherson region)", Thesis abstract of Cand. Sc. (Econ.), 08.06.01, Kyiv National Economic University named after Vadym Hetman, Kyiv, Ukraine, 2006.

[32] T.B. Kharchenko, "Quality of products in the system of factors of competitiveness of enterprise", Thesis abstract of Cand. Sc. (Econ.), 08.06.01, Shevchenko Kiev National University, Kyiv, Ukraine, 2006.

[33] T.V. Shypysh and N.A. Luniakova, "Review of methods for estimation the competitiveness of enterprises", Aktualnyie problemyi konkurentosposobnosti predpriyatiy [Actual problems of competitiveness of the enterprises], Materialyi Vseukrainskoy nauchno-prakticheskoy konferentsii studentov, aspirantov, molodyih uchYonyih [Proceedings of the All-Ukrainian scientific-practical conference of students, graduate students, young scientists], (Sevastopol, 22-23 April 2010), 2010, pp. 252-254.

[34] N.M. Semko, English-Ukrainian Dictionary of Business, Oriâna-Nova, Lviv, Ukraine, 2006.

[35] K.O. Vaskovska, Metodičnij pìdhìd ŝodo provedennâ kompleksnogo analìzu v sistemì upravlìnnâ konkurentospromožnìstû pìdpriêmstva [Methodical approach to complex analysis in the enterprise competitiveness management system] in Nemchenko V. (ed.), Naukovo-metodičnì aspekti oblikovoanalitičnoï sistemi pidpriêmstva [Scientific and methodical aspects of the accounting and analytical system of the enterprise], Fenìks, Odesa, Ukraine, pp. 200-208, 2016. 